\section{Australian Journal of \\ Crop Science}

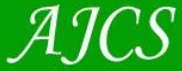

ISSN:1835-2707

AJCS 13(02):192-198 (2019)

doi: 10.21475/ajcs.19.13.02.p1146

\title{
Investigation of heavy metal accumulation in soil, water and plants in areas with intensive horticulture
}

Laércio Santos Silva ${ }^{1}$, Izabel Cristina de Luna Galindo ${ }^{2}$, Romário Pimenta Gomes ${ }^{1}$, Vinícius Augusto Filla ${ }^{3}$, Milton César Costa Campos ${ }^{4 *}$, Ludmila de Freitas ${ }^{5}$, Ivanildo Amorim de Oliveira ${ }^{5}$, Karina Patrícia Prazeres Marques $^{6}$, Edicarlos Damacena de Souza ${ }^{7}$, Jairo Osvaldo Cazzeta ${ }^{1}$

${ }^{1}$ Department of Soils and Fertilizers, School of Agricultural and Veterinary Studies (FCAV), São Paulo State University (UNESP), 14.870-900, Jaboticabal, São Paulo, Brazil

${ }^{2}$ Department of Agronomy, Rural Federal University of Pernambuco (UFRPE), 52.171-900, Recife, Pernambuco, Brazil

${ }^{3}$ Department of Crop Production, School of Agricultural and Veterinary Studies (FCAV), São Paulo State University (UNESP), 14.870-900, Jaboticabal, São Paulo, Brazil

${ }^{4}$ Institute of Education, Agriculture and Environment, Federal University of Amazonas (UFAM), 69.800-000, Humaitá, Amazonas, Brazil

${ }^{5}$ Federal Institute of Education, Science and Technology of Pará (IFPA), 68.800-000, Breves, Pará, Brazil

${ }^{6}$ Department of Soil Science, Luiz de Queiroz College of Agriculture (ESALQ), University of São Paulo (USP), 13.418900, Piracicaba, São Paulo, Brazil

${ }^{7}$ University Campus of Rondonópolis, Federal University of Mato Grosso (UFMT), 78.735-910, Rondonópolis, Mato Grosso, Brazil

*Corresponding author: mcesarsolos@gmail.com

\section{Abstract}

The content and availability of heavy metals in intensively cultivated soils are important issues because these metals are potential environmental contaminants and toxic to living beings. Thus, the aim of this study was to evaluate the levels of $\mathrm{Cd}, \mathrm{Mn}, \mathrm{Cu}, \mathrm{Pb}, \mathrm{Ni}$ and $\mathrm{Zn}$ available in the soil of five agricultural areas compared to the soil of adjacent native forests, to determine the risk of soil, water and plant contamination. A total of 180 soil samples were collected at two depths $(0.00-0.10$ and $0.10-0.30 \mathrm{~m})$, and edible samples were extracted from plants cultivated in these soils. Water samples were taken from reservoirs commonly used to irrigate these crops and from well water used for human consumption. All the samples were subjected to heavy metal extraction methods $\left(\mathrm{HNO}_{3}+\mathrm{HCl}+\mathrm{DTPA}\right)$ and measurements were carried out by atomic absorption spectrometry. The results showed that soil with intensive agricultural inputs increased $\mathrm{Mn}, \mathrm{Cu}$ and $\mathrm{Zn}$ levels. High levels of $\mathrm{Ni}$ were found even in agricultural and forest soils, indicating that this may be associated with its presence in the original soil material. $\mathrm{Pb}$ and $\mathrm{Ni}$ levels exceeded the maximum values allowed by ANVISA (Brazilian Health Regulatory Agency) for all plant samples examined. Bell pepper and chard showed the highest levels of $\mathrm{Pb}$ and $\mathrm{Ni}$, suggesting that these species accumulate more $\mathrm{Pb}$ and $\mathrm{Ni}$ compared to other species studied. Levels of $\mathrm{Cd}, \mathrm{Ni}$ and $\mathrm{Pb}$ surpassed the values established by CONAMA (National Council for the Environment) for human consumption and irrigation water, and the levels were influenced by seasonal rainfall. Preventive monitoring and planning of fertilizer applications, in order to avoid fertilizing the soil near the rainy season, are alternatives to establish normal heavy metal levels in human consumption and irrigation water. Moreover, bell pepper and chard should not be grown in $\mathrm{Pb}$ and $\mathrm{Ni}$ contaminated soils.

Keywords: Anthropic action; Agriculture; Bioavailability; Environmental pollution; Potentially toxic element; Agricultural management.

Abbreviations: A_vegetable crop areas; ANVISA_Brazilian Health Regulatory Agency; CONAMA_National Council for the Environment; DAP_diammonium phosphate; DTPA_diethylenetriaminepentaacetic acid; LD_detection limit; M_native forest areas; MAP_monoammonium phosphate; MO_organic matter; MTL_ Maximum Tolerate Limit; NPK_nitrogen, phosporus and potassium; R_Reservoirs; RQL_Reference Quality Level.

Introduction

The increase in agricultural production is strictly related to the use of technology and inputs, such as the intensive application of chemical fertilizers (Pingali, 2012). However, their inadequate use, especially phosphates, is the primary input of potentially polluting substances in the agricultural ecosystem (Nziguheba and Smolders, 2008; Atafar et al., 
2010). According to Silva et al. (2016), natural soil Cd, Mn, $\mathrm{Cu}, \mathrm{Pb}, \mathrm{Ni}$ and $\mathrm{Zn}$ levels depend on the material of origin and degree of pedogenesis, thereby occurring in low concentrations that do not threaten human health or the environment.

Chemical neutralizers and conditioners such as phosphate fertilizers are commonly applied to raise the productive potential of soil. These practices increase the natural levels of heavy metals in soil, since they are not eliminated during the fertilizer manufacturing process (Silva et al., 2016). More important than the total heavy metal content in soil is the fraction available to plants, that is, the concentration of metals in soil solution (Ali et al., 2013). This fraction depends on the physical and chemical conditions of soil, as well as the management system adopted (Gupta et al., 2014). Soils with higher $\mathrm{pH}$ adsorb more $\mathrm{Cd}$ and $\mathrm{Pb}$, which reduces their absorption by plants (Mclaughlin et al., 2011). In soils with acid $\mathrm{pH}$, the activity of $\mathrm{Fe}^{2+}, \mathrm{Mn}^{2+}, \mathrm{Zn}^{2+}$ and $\mathrm{Ca}^{2+}$ strengthens competition for $\mathrm{Cd}, \mathrm{Pb}$, and $\mathrm{Zn}$ exchange sites, making them more easily available to plants or leached to the water table.

Consumption of plants contaminated by heavy metals is the primary contamination pathway of the trophic chain, responsible for triggering cell mutation (cancer) and neurological disorders in human beings (Singh et al., 2010; Khan et al., 2012; Mahmood and Malik, 2014). However, plant absorption potential depends on the species, and some accumulate or tolerate more than others without manifesting toxic symptoms (Singh et al., 2010).

According to Weingerl and Kerin (2000), Zn content in soils planted with vegetable crops increases annually from 0.5 to $1 \mathrm{mg} \mathrm{kg}$, due to the use of fungicides and fertilizers containing $\mathrm{Zn}$ in their formulation, such as copper foliar fertilizers ( $\mathrm{Zn}, \mathrm{Cu}$ and $\mathrm{Mn} \approx 21 \%, 4 \%$ and $3 \%$, respectively), commonly used to restore $\mathrm{Zn}$ in tomato, bell pepper and chard crops. In China, Singh et al. (2010) warned of the potential risk to human health from ingesting vegetables commonly irrigated with Cd-contaminated water, a fact also reported by Khan et al. (2012).

Although the concern about increased heavy metal content in the soil, water and plant system is worldwide, few studies have comprehensively investigated heavy metal accumulation in soil, water and plants (Fernandes et al., 2007). In order to fill this gap and promote prevention and remediation research, the present study aimed to analyze total $\mathrm{Cd}, \mathrm{Mn}, \mathrm{Cu}, \mathrm{Pb}, \mathrm{Ni}$ and $\mathrm{Zn}$ content (soil, water and plant) available in areas with vegetable crops and native forest, demonstrating the risk of environmental and human contamination.

\section{Results and Discussion}

Total content and metal availability in agricultural and forest soils

Heavy metal concentrations in crop areas varied for $\mathrm{Cd}(0.22$ $\left.-0.66 \mathrm{mg} \mathrm{kg}^{-1}\right), \mathrm{Cu}\left(3.9-12.3 \mathrm{mg} \mathrm{kg}{ }^{-1}\right), \mathrm{Mn}(25.6-163) \mathrm{mg}$ $\left.\mathrm{kg}^{-1}\right), \mathrm{Ni}\left(12-41 \mathrm{mg} \mathrm{kg}^{-1}\right), \mathrm{Pb}\left(1.3-6.6 \mathrm{mg} \mathrm{kg}^{-1}\right)$ and $\mathrm{Zn}(9-$ $\left.22 \mathrm{mg} \mathrm{kg}^{-1}\right)$, while in reference (forest) areas, they varied for $\mathrm{Cd}\left(0.28-0.58 \mathrm{mg} \mathrm{kg}^{-1}\right), \mathrm{Cu}\left(2.63-4.48 \mathrm{mg} \mathrm{kg}^{-1}\right), \mathrm{Mn}(13-$ $\left.18.6 \mathrm{mg} \mathrm{kg}^{-1}\right), \mathrm{Ni}\left(37-58 \mathrm{mg} \mathrm{kg}^{-1}\right), \mathrm{Pb}\left(1.88-4.78 \mathrm{mg} \mathrm{kg}^{-1}\right)$ and $\mathrm{Zn}\left(1.95-8.33 \mathrm{mg} \mathrm{kg}^{-1}\right.$ ) (Fig. 2). Except for $\mathrm{Zn}, \mathrm{Pb}$ and $\mathrm{Ni}$, the other heavy metals exhibited considerably higher than natural levels at some sampling points, and only $\mathrm{Cd}$ and $\mathrm{Cu}$ concentrations were above the maximum permissible limit of $0.5 \mathrm{mg} \mathrm{kg}^{-1}$ and $5 \mathrm{mg} \mathrm{kg}^{-1}$, respectively.

The fraction immediately available to plants (Fig. 2) shows that the amounts of $\mathrm{Ni}$ and $\mathrm{Pb}$ available are insignificant compared to the total soil content, with a slight increase in $\mathrm{Ni}$ observed in $\mathrm{A} 5 \mathrm{and} \mathrm{Pb}$ in $\mathrm{A} 2$ and $\mathrm{A} 5$, at both depths. However, only concentrations of $\mathrm{Zn}\left(2-11 \mathrm{mg} \mathrm{kg}^{-1}\right)$ in all the areas and at both depths are considered extremely high, according to Raij et al. (1997), who established $1.2 \mathrm{mg} \mathrm{kg}^{-1}$ as elevated.

The $\mathrm{Pb}$ concentrations were negligible, that is, below the minimum detection value of the device, especially in area A3. This can be demonstrated by analyzing the total portion of this element below the detection limit of the equipment (detection limit $=0.003$ ). This leads to the conclusion that $\mathrm{Pb}$ is not part of the geochemical environment of Area 3 soil, likely because it is located in the arenite-gneiss transect, and reinforces the idea that there is no increase in this element as a result of anthropic action. Given the proximity of areas A3 and A4, forest area M4 was used to identify the origin of metals in soil. However, the findings obtained indicate that the $M 3$ soil best represents the potential of area $A 4$ in supplying $\mathrm{Pb}$. Thus, no inferences were made for $\mathrm{A} 3$, taking M3 soil as reference, since there was a risk of reaching the wrong conclusions.

The lower concentrations of $\mathrm{Cd}$ and $\mathrm{Cu}$ available in the forest soil indicate anthropic origin in agricultural areas (Fig. 2). This decrease is a consequence of using copper fungicides such as copper hydroxide to control bacterial spot in tomato and bell pepper. This is because the high humidity of the region favors Xanthomonas species ( $X$. vesicatoria, $X$. euvesicatoria, $X$. perforans and $X$. gardneri), which cause bacterial spot (Jones et al., 2004). The increase in $\mathrm{Cu}$ was also observed by Casali et al. (2008) in soils planted with grapevines compared to native forest soils, and this effect was attributed to the use of copper fungicides.

Among all the metals studied, the highest contents were found for $\mathrm{Mn}$. Although there is no regulation that stipulates the natural level of this element in soil, a comparison with reference levels indicates a rise in anthropic $\mathrm{Mn}$, given that the metal levels in forest soil are around 10 times lower than those of agricultural soils. The high $\mathrm{Mn}$ content corroborates a number of studies (Ramalho et al., 2000; Fernandes et al., 2007; Biondi et al., 2011; Preston et al., 2016), showing the need for legislation governing the Quality Reference Value of this metal in soil and plants.

Table 2 shows the properties of planted soils that are most associated with the heavy metals studied. In general, the strong correlations with chemical properties easily altered by using agricultural inputs reinforce the assumption that the management of these areas is the primary source of toxic elements in soil. According to the literature, the strong correlations between $\mathrm{Cd}(\mathrm{r}=0.53 ; \mathrm{r}=0.63)$ and $\mathrm{P}$ confirm the contribution of phosphate fertilizers, which are widely used due to the low phosphorous content of residual sandygneiss soil, in addition to the advanced pedogenesis of the soil.

The dynamics of metals in soil seem to depend on the quality of the clay fraction and $\mathrm{pH}$. As in $\mathrm{Mn}$, the significant correlation between $\mathrm{Mn}$ and $\mathrm{pH}$, positive at a depth of 0.00 $0.10 \mathrm{~m}$ and negative at $0.10-0.30 \mathrm{~m}$, demonstrates the different states of oxidation in the soil, whose speciation 
Table 1. Chemical and granulometric characterization of soil from vegetable crops and forests at two depths in the subareas studied.

\begin{tabular}{|c|c|c|c|c|c|c|c|c|c|c|c|}
\hline \multirow{2}{*}{$\begin{array}{l}\text { Soil } \\
\text { property }\end{array}$} & \multirow{2}{*}{ Unit } & \multicolumn{5}{|c|}{ Vegetable subarea } & \multicolumn{5}{|c|}{ Forest subarea } \\
\hline & & $\mathrm{A} 1$ & $\mathrm{~A} 2$ & $\mathrm{~A} 3$ & A4 & A5 & M1 & $\mathrm{M} 2$ & M3 & M4 & M5 \\
\hline \multicolumn{12}{|c|}{ Depth $0.00-0.10 \mathrm{~m}$} \\
\hline $\mathrm{pH}\left(\mathrm{H}_{2} \mathrm{O}\right)$ & \multirow{4}{*}{$\mathrm{cmol}_{\mathrm{c}} \mathrm{dm}^{-3}$} & 6.2 & 6.1 & 5.7 & 5.6 & 6.5 & 4.8 & 4.6 & 4.6 & 4.2 & 4.2 \\
\hline $\mathrm{Ca}^{2+}$ & & 5.0 & 4.0 & 3.2 & 4.1 & 4.5 & 1.5 & 1.3 & 1.0 & 0.8 & 0.8 \\
\hline $\mathrm{Mg}^{2+}$ & & 2.2 & 2.6 & 1.1 & 2.3 & 2.9 & 3.2 & 1.5 & 2.7 & 3.0 & 3.0 \\
\hline $\mathrm{K}^{+}$ & & 1.6 & 1.0 & 0.3 & 2.0 & 2.4 & 0.5 & 0.1 & 0.2 & 0.2 & 0.2 \\
\hline$P$ & $\mathrm{mg} \mathrm{dm} \mathrm{m}^{-3}$ & 172 & 275 & 137 & 246 & 44 & 8.0 & 6.0 & 8.0 & 5.0 & 5.0 \\
\hline MO & \multirow{4}{*}{$\mathrm{g} \mathrm{kg}^{-1}$} & 25.2 & 30.3 & 14.8 & 24.2 & 24.4 & 45.5 & 43.2 & 38.6 & 39.7 & 39.7 \\
\hline Clay & & 560 & 420 & 580 & 730 & 540 & 370 & 610 & 570 & 600 & 540 \\
\hline Silt & & 160 & 60 & 60 & 60 & 120 & 60 & 80 & 210 & 190 & 120 \\
\hline Sand & & 280 & 520 & 360 & 210 & 340 & 570 & 310 & 220 & 210 & 340 \\
\hline \multicolumn{12}{|c|}{ Depth $0.10-0.30 \mathrm{~m}$} \\
\hline $\mathrm{pH}\left(\mathrm{H}_{2} \mathrm{O}\right)$ & \multirow{4}{*}{$\mathrm{cmol}_{\mathrm{c}} \mathrm{dm}^{-3}$} & 5.5 & 5.9 & 5.7 & 5.5 & 6.4 & 4.5 & 4.6 & 4.5 & 4.4 & 6.4 \\
\hline $\mathrm{Ca}^{2+}$ & & 2.7 & 3.3 & 3.1 & 3.6 & 3.7 & 1.3 & 1.2 & 1.1 & 0.6 & 3.7 \\
\hline $\mathrm{Mg}^{2+}$ & & 2.6 & 2.9 & 0.7 & 1.9 & 0.9 & 1.5 & 2.5 & 1.6 & 1.7 & 0.9 \\
\hline $\mathrm{K}^{+}$ & & 1.7 & 0.7 & 0.1 & 0.6 & 1.1 & 0.6 & 0.1 & 0.1 & 0.1 & 1.1 \\
\hline $\mathrm{P}$ & \multirow[t]{2}{*}{$\mathrm{mg} \mathrm{dm^{-3 }}$} & 107 & 62 & 136 & 176 & 36 & 5.0 & 4.0 & 3.0 & 4.0 & 36 \\
\hline MO & & 26.1 & 19.1 & 11 & 14.3 & 22.5 & 43.2 & 38.6 & 32.6 & 33.4 & 22.5 \\
\hline Clay & \multirow{3}{*}{$\mathrm{g} \mathrm{kg}^{-1}$} & 610 & 540 & 500 & 560 & 730 & 450 & 570 & 550 & 540 & 730 \\
\hline Silt & & 100 & 240 & 80 & 170 & 100 & 160 & 120 & 120 & 90 & 100 \\
\hline Sand & & 290 & 220 & 420 & 207 & 170 & 390 & 310 & 330 & 370 & 170 \\
\hline
\end{tabular}

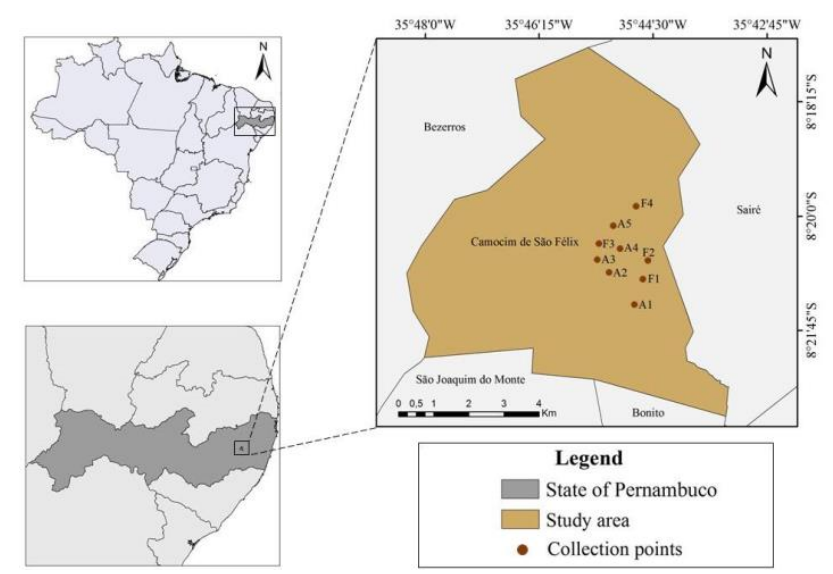

Fig 1. Location of the study area and subareas sampled ( $A 1, A 2, A 3, A 4$ and $A 5=$ areas with vegetable crops; F1, F2, F3, F4 and F5 = areas of native forest.)

Table 2. Pearson's correlation coefficient between soil heavy metals and soil chemical properties and clay content in agricultural areas at two depths.

\begin{tabular}{|c|c|c|c|c|c|c|c|c|c|c|}
\hline \multirow[t]{3}{*}{ Metals } & \multicolumn{10}{|c|}{ Textural and chemical levels } \\
\hline & Clay & $\mathrm{pH}$ & $\mathrm{Ca}$ & $\mathrm{Mg}$ & $\mathrm{K}$ & $\mathrm{P}$ & $\mathrm{H}+\mathrm{Al}$ & $\mathrm{Al}$ & $\mathrm{MO}$ & CTC \\
\hline & & \multicolumn{9}{|c|}{ Depth $0.00-0.10 \mathrm{~m}$} \\
\hline $\mathrm{Cd}$ & $0.80^{*}$ & $-0.55 * *$ & $-0.90 *$ & $-0.68^{*}$ & $0.18^{\text {ns }}$ & $0.53 * *$ & $0.78^{*}$ & $0.72^{*}$ & $0.42^{\text {ns }}$ & $0.06^{\text {ns }}$ \\
\hline $\mathrm{Cu}$ & $-0.59 * *$ & $-0.60^{\text {ns }}$ & $-0.68^{\mathrm{ns}}$ & $0.91^{\mathrm{ns}}$ & $0.60 *$ & $0.28^{\mathrm{ns}}$ & $0.33^{\mathrm{ns}}$ & $0.04^{\mathrm{ns}}$ & $0.63^{*}$ & $0.91 *$ \\
\hline $\mathrm{Mn}$ & $-0.80^{*}$ & $0.58 * *$ & $0.89 *$ & $0.63^{*}$ & $-0.39^{\text {ns }}$ & $0.34^{\mathrm{ns}}$ & $-0.80 *$ & $-0.94 *$ & $-0.17^{\text {ns }}$ & $-0.11^{\mathrm{ns}}$ \\
\hline $\mathrm{Ni}$ & $0.009^{\mathrm{ns}}$ & $0.98^{*}$ & $-0.04^{\mathrm{ns}}$ & $-0.43^{\mathrm{ns}}$ & $0.06^{\mathrm{ns}}$ & $-0.52^{\mathrm{ns}}$ & $-0.87^{*}$ & $-0.69 *$ & $0.31^{\mathrm{ns}}$ & $-0.95^{*}$ \\
\hline $\mathrm{Pb}$ & $0.65^{*}$ & $-0.79 *$ & $-0.72^{*}$ & $-0.38^{\text {ns }}$ & $0.36^{\mathrm{ns}}$ & $-0.43^{\mathrm{ns}}$ & $0.94 *$ & $0.85^{*}$ & $0.62 *$ & $0.40^{\mathrm{ns}}$ \\
\hline \multirow[t]{2}{*}{$\mathrm{Zn}$} & $0.42^{\mathrm{ns}}$ & $-0.95^{*}$ & $-0.44^{\text {ns }}$ & $-0.05^{\mathrm{ns}}$ & $-0.07^{\mathrm{ns}}$ & $0.51 * *$ & $0.99 *$ & $0.95^{*}$ & $0.31^{\mathrm{ns}}$ & $0.68 *$ \\
\hline & & \multicolumn{9}{|c|}{ Depth $0.10-0.30 \mathrm{~m}$} \\
\hline $\mathrm{Cd}$ & $-0.001^{\mathrm{ns}}$ & $0.94 *$ & $0.37^{\mathrm{ns}}$ & $0.99 *$ & $0.19^{\text {ns }}$ & $0.64^{*}$ & $-0.98 *$ & $0.98^{*}$ & $0.05^{\mathrm{ns}}$ & -0.42 \\
\hline $\mathrm{Cu}$ & $-0.55 * *$ & $-0.30^{\text {ns }}$ & $0.52 * *$ & $-0.71 *$ & $0.57^{* *}$ & $-0.29^{\mathrm{ns}}$ & $0.41^{\mathrm{ns}}$ & $-0.78 *$ & $0.56^{* *}$ & $0.98 *$ \\
\hline $\mathrm{Mn}$ & $-0.38^{\mathrm{ns}}$ & $-0.60^{*}$ & $0.21^{\mathrm{ns}}$ & $-0.90 *$ & $-0.31^{\mathrm{ns}}$ & $0.48^{* *}$ & $0.69 *$ & $-0.94 *$ & $-0.32^{\mathrm{ns}}$ & $0.85^{*}$ \\
\hline $\mathrm{Ni}$ & $-0.40^{\text {ns }}$ & $0.95^{*}$ & $0.84 *$ & $0.70 *$ & $-0.10^{\mathrm{ns}}$ & $-0.37^{\mathrm{ns}}$ & $-0.91^{*}$ & $0.62 *$ & $0.14^{\mathrm{ns}}$ & $0.18^{\mathrm{ns}}$ \\
\hline $\mathrm{Pb}$ & $0.58 * *$ & $0.23^{\mathrm{ns}}$ & $-0.58 * *$ & $0.65^{*}$ & $0.34^{\mathrm{ns}}$ & $-0.68 *$ & -0.34 & $0.74^{*}$ & $0.79 *$ & $-0.99 *$ \\
\hline $\mathrm{Zn}$ & $0.42^{\mathrm{ns}}$ & $-0.94 *$ & $-0.85^{*}$ & $-0.69 *$ & $0.32^{\mathrm{ns}}$ & $0.15^{\mathrm{ns}}$ & $0.90 *$ & $-0.60 *$ & $-0.09^{\mathrm{ns}}$ & -0.20 \\
\hline
\end{tabular}




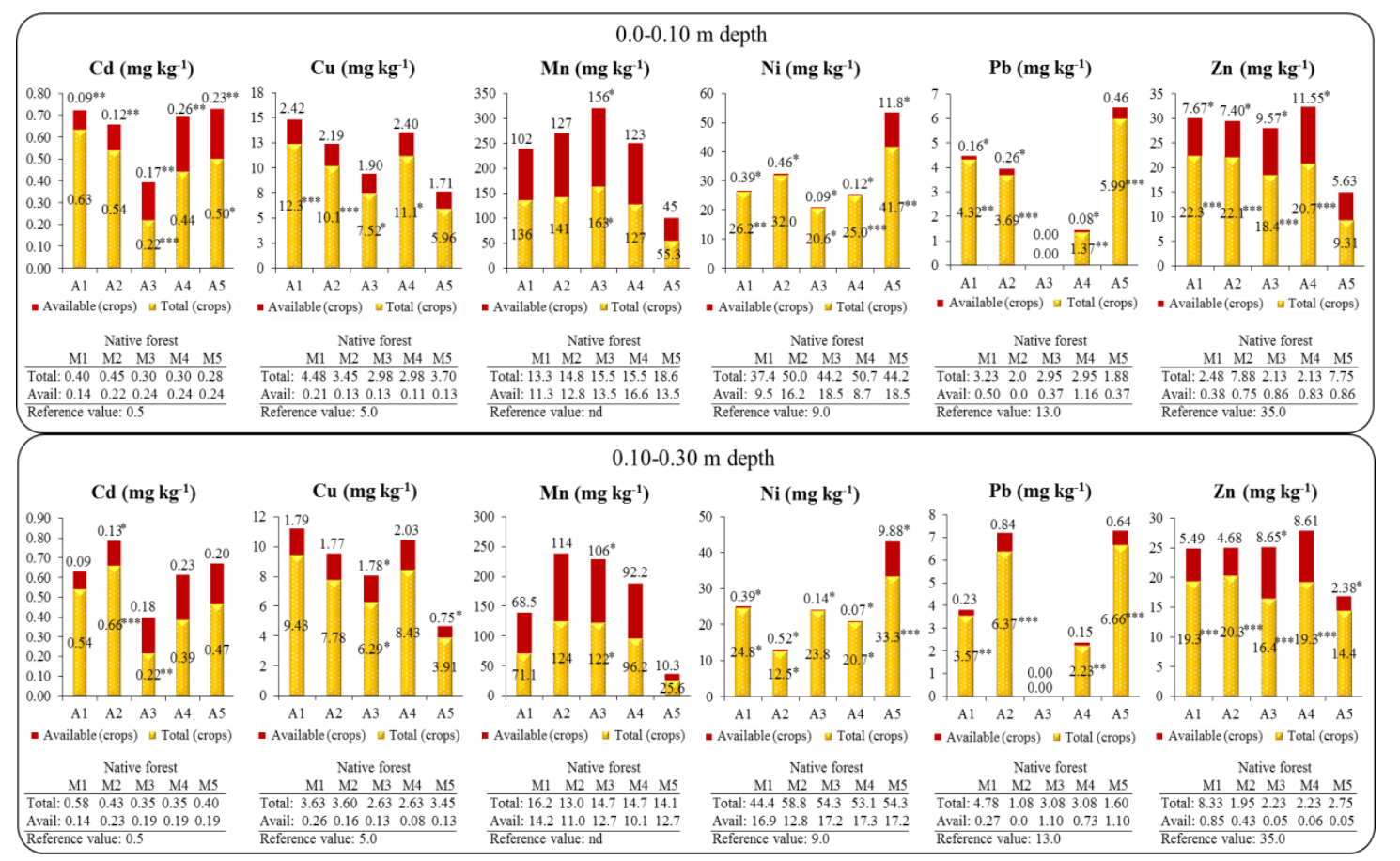

Fig 2. Comparison between total and available metal levels in soil planted with vegetables $(V)$ and native forest $(F)$. nd $=$ not detected. * Differs statistically from the forest area (significant at $5 \%$ using the t-test).

Table 3. Mean heavy metal levels in the edible parts of different vegetables from two crops $\left(1^{\text {st }}\right.$ and $\left.2^{\text {nd }}\right)$ in five agricultural areas of Camocim de São Felix, Pernambuco (PE) state.

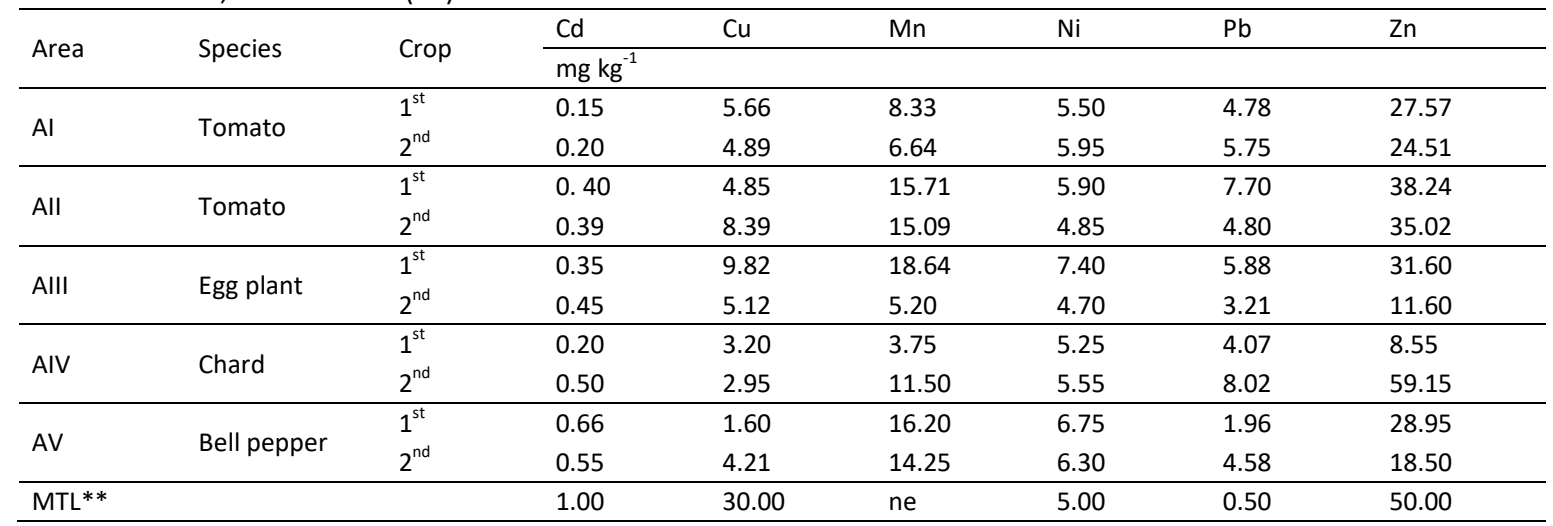

** Maximum tolerated limit in plants (Anvisa, 1965); ns: not specific.

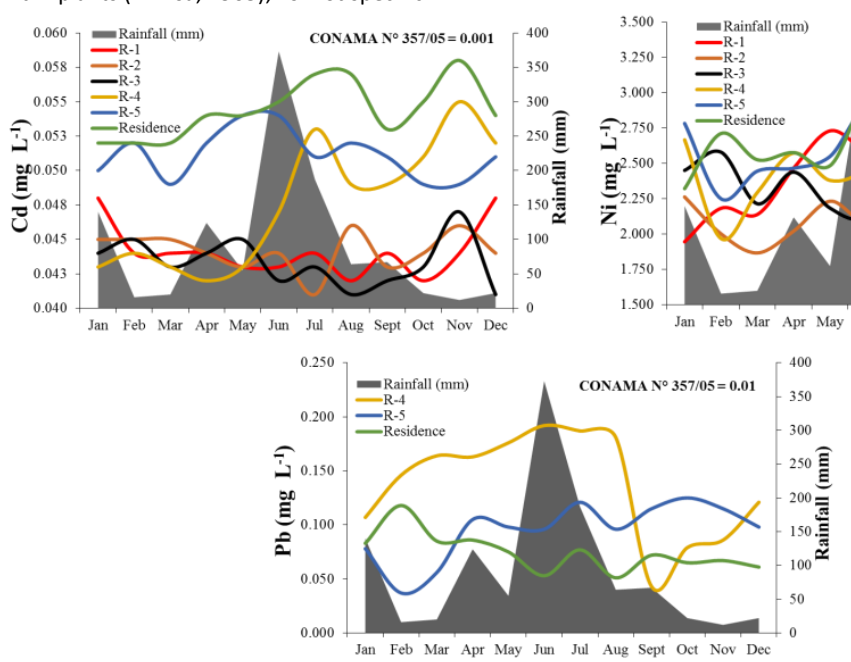

Fig 3. Average heavy metal content in the water samples of five reservoirs ( $R$ ) and an artesian well used to irrigate vegetable crops for human and animal consumption in the municipality of Camocim de São Félix, Pernambuco state (PE). 
depends on $\mathrm{pH}$ and oxidation-reduction potential, as reported by Biondi et al. (2011).

The positive correlations for $\mathrm{Cu}(r=0.63 ; 0.56)$ and $\mathrm{Pb}(0.62$; $0.79)$, which were the only highly significant ones $(p<0.01$ and 0.05 ) with OM at both depths, suggest that these metals have the same reserve source, namely organic matter. For $\mathrm{Cu}$, this behavior is most likely associated with its high affinity for carboxylic and phenolic groups of OM (Casali et al., 2008; Melo et al., 2008; Silva and Vitti, 2008) which results in low desorption capacity (Lair et al., 2006).

Agricultural practices widely used in horticulture, such as applying urea to increase the leaf mass of plant crops, as well as ammonium fertilizers, may acidify the soil. This explains the negative correlations between $\mathrm{Cu}(r=0.60)$ and $\mathrm{Pb}(r=0.79)$ and soil $\mathrm{pH}$, since acidification causes these elements to detach from the mineral fractions, facilitating the availability of $\mathrm{Cu}$ and $\mathrm{Pb}$ at $0.00-0.10 \mathrm{~m}$. On the other hand, $\mathrm{Pb}(\mathrm{r}>0.58)$ and $\mathrm{Cd}(\mathrm{r}=0.80)$ were strongly related to the clay fraction. According to Araújo et al. (2002) and McLaughlin et al. (2011), this is due to the formation of clay$\mathrm{Pb}-\mathrm{Cd}$-organic matter complexes and the participation of $\mathrm{Fe}$ and $\mathrm{Al}$ oxides in this process, as well as the substantial specific surface area of the clay fraction. As such, the amount of metals available to the plant declines (Gupta et al., 2014).

\section{Bioaccumulation of soil heavy metals in the plants}

The minimum and maximum levels in the vegetable dry matter ( $\mathrm{mg} \mathrm{kg}^{-1}$ dry matter) were $0.15-0.66 \mathrm{mg} \mathrm{kg}^{-1}, 1.6-$ $9.82 \mathrm{mg} \mathrm{kg}^{-1} ; 3.75-18.64 \mathrm{mg} \mathrm{kg}^{-1}, 4.70-7.40 \mathrm{mg} \mathrm{kg}^{-1} ; 1.96-$ $8.02 \mathrm{mg} \mathrm{kg}^{-1}$ and $11.60-59.15 \mathrm{mg} \mathrm{kg}^{-1}$, respectively for $\mathrm{Cd}$, $\mathrm{Cu}, \mathrm{Mn}, \mathrm{Ni}, \mathrm{Pb}$ and $\mathrm{Zn}$. Although the high $\mathrm{Cd}$ levels in the agricultural soils of areas $\mathrm{A} 1, \mathrm{~A} 2$ and $\mathrm{A} 5$ were higher than QRVs, their content in vegetables was lower than the Maximum Tolerable Limit (MTL) in food (Table 3) (ANVISA, 1965). This same response pattern was observed for $\mathrm{Cu}$ and $\mathrm{Zn}$. In the case of $\mathrm{Pb}$, the content in the vegetables assessed was significantly higher than the MLT. Soil Ni displayed a response similar to that of $\mathrm{Cd}$, although in area $\mathrm{A} 5$, its content was near the prevention value at both depths. However, the $\mathrm{Ni}$ content in the vegetables was higher than the MLT, except in the second tomato crop at A2 and eggplant at A3.

Among the agricultural areas, $\mathrm{A} 4$ exhibited the highest $\mathrm{Pb}$ levels, followed by A5 (chard), A2 (tomato), A3 (eggplant) and $A 1$ (tomato) (Table 3). On the other hand, A5 (bell pepper) displayed the highest $\mathrm{Ni}$ levels, followed by $\mathrm{A} 3$ (eggplant), A1 and A2 (tomato) and A4 (chard). Differences in absorption and heavy metal accumulation by plants occur because vegetables have varying capacities to absorb and accumulate them (Singh et al., 2010), even when growing in soils with harmful levels, as demonstrated here for $\mathrm{Pb}$, whose soil content was lower than the prevention value (Conama, 2009).

Total contents in the vegetables were higher than those reported by Ramalho et al. (2000) in a micro basin with intensive use of agrochemicals, but similar to the $\mathrm{Cd}, \mathrm{Pb}$ and $\mathrm{Cu}$ values found by Fernandes et al. (2007). However, the Pb content was similar in all the vegetables analyzed, with values much higher than the $0.5 \mathrm{mg} \mathrm{kg}^{-1}$ MTL established by ANVISA (1965), followed by Ni, with an MTL of $5 \mathrm{mg} \mathrm{kg}^{-1}$. Although the available soil $\mathrm{Pb}$ and $\mathrm{Ni}$ levels were not high, they were elevated in the vegetables (Table 3). Silva et al.
(2016) investigated these areas and observed the same behavior, attributing it to the excessive use of poultry litter, which contains $\mathrm{Pb}$ and $\mathrm{Ni}$ from poultry feed.

\section{Heavy metals in water}

Except for $\mathrm{Zn}, \mathrm{Cu}$ and $\mathrm{Mn}$, the reservoir water used to irrigate the subarea vegetable crops had higher $\mathrm{Cd}, \mathrm{Ni}$ and $\mathrm{Pb}$ levels than those allowed by CONAMA (2005) of 0.001 , 0.025 and $0.01 \mathrm{mg} \mathrm{L}^{-1}$, respectively (Fig. 3 ), with values ranging from 0.04 to $0.05 \mathrm{mg} \mathrm{L}^{-1}, 2.19$ to $2.86 \mathrm{mg} \mathrm{L}^{-1}$ and 0.08 to $0.14 \mathrm{mg} \mathrm{L}^{-1}$ for $\mathrm{Cd}, \mathrm{Ni}$ and $\mathrm{Pb}$, respectively. The artesian well water (R-6), used for human and animal consumption, showed similar levels to those of the other reservoirs (Fig. 3), likely compromising the local food chain, with harmful effects on health and the quality of life of farmers and consumers of agricultural products.

Water from reservoir R5 exhibited the highest $\mathrm{Pb}$ levels (around $0.14 \mathrm{mg} \mathrm{kg}^{-1}$ ) (Fig. 3). This reservoir supplies area A5, cultivated with vegetables, likely explaining the highest soil $\mathrm{Pb}$ levels observed there. Ramalho et al. (2000) studied water contamination in vegetable producing areas of the Paty do Alferes micro basin in Rio de Janeiro state and found $\mathrm{Pb}$ values that exceeded the legal limits, considerably higher (145 times) than those detected in the present study. The Ni values in water samples varied from 2.19 to $2.86 \mathrm{mg}$ $\mathrm{L}^{-1}$, approximately 100 times higher than the permissible limit of $0.025 \mathrm{mg} \mathrm{L}^{-1}$ (CONAMA, 2005). These values indicate strong $\mathrm{Ni}$ contamination in bodies of water and, as such, may contaminate soil and plants due to the cyclic process of water use. The increase in $\mathrm{Ni}$ content after intense rainfall (January and June) is likely due to the infiltration of metal adsorbed to the sediments transported to the reservoirs by erosion processes.

In general, $\mathrm{Cd}, \mathrm{Ni}$ and $\mathrm{Pb}$ concentrations in soil and water used for both crop irrigation and human consumption were above maximum legal standards (CONAMA, 2005; 2009), revealing strong anthropic participation and causing risks to the population of Camocim de São Felix, PE, who are directly or indirectly exposed to these potentially toxic metals. Thus, more studies are needed in these areas, in order to help and guide soil remediation.

\section{Materials and Methods}

\section{General description of the study areas}

Five agricultural areas were selected in the municipality of Camocim de São Félix, Pernambuco state, Brazil (Fig. 1). The crops are grown on a slope and the site has its own reservoir for irrigation and another (artesian well) for human consumption. Native forest surrounds the study area, which was all formerly covered by semi-deciduous and/or subperennial vegetation (Brazil, 1973). The region exhibits uneven terrain (concave-convex) with a slope of around 32\% and altitude of 1000 meters. According to the Köppen classification, Aw is the predominant climate in the region (Brazil, 1973), characterized by annual average temperature and rainfall of $24{ }^{\circ} \mathrm{C}$ and $1100 \mathrm{~mm}$, respectively.

The soil in the agricultural and native forest areas is Yellow Latosol (Embrapa, 2013), corresponding to Xanthic Ferralsol in the IUSS/WRB classification (2015), developed from arenite and gneiss (Brazil, 1973). Physical and chemical analyses of the soil samples collected in the study areas are 
shown in Table 1 . These areas have been used to grow vegetables for over 50 years, the primary agricultural activity in the region. They are cultivated year-round with tomatoes, chard, bell pepper and eggplant, which grow in short furrows within plots or in rows where the seeds and/or seedlings are planted.

Due to the poor soil chemical and organic properties, chemical and organic fertilizers (primarily poultry litter) as well as preventive and corrective pesticides are often applied, all with little technical expertise. The fertilizers and pesticides used include the following chemical groups: organophosphate, isophthalonitrile, benzimidazole, azoxystrobin (strobilurin), cyproconazole (triazole), alkylene bis (dithiocarbamate), pyrethroid, benzofuranyl methylcarbamate, monoammonium phosphate (MAP), diammonium phosphate (DAP), simple superphosphate, triple superphosphate, magnesium thermophosphate and several types of NPK (06-24-12; 20-10-20; 10-10-10; 10-2020 and 20-0-20), among others.

\section{Soil sampling}

Ten simple soil samples were collected along the rows of the five 1.2 to 1.8 ha subareas of vegetable crops (A1, $A 2, A 3, A 4$ and $A 5)$, at two depths $(0.00-0.10$ and $0.10-0.30 \mathrm{~m})$. Forest soil (M1, M2, M3, M4 and M5) was sampled in a zigzag pattern in subareas the same size as the vegetable areas and at the same depths, where 10 simple homogenized samples were collected to form a compound sample (Fig. 1). The forest areas include fragments of secondary forest vegetation at the top of hillsides, with minimal anthropic intervention. Because of the proximity between areas $\mathrm{A} 3$ and $\mathrm{A} 4$, their heavy metal contents were compared with those of M3 (Fig. 1).

\section{Plant sampling}

For the plant material, the edible part ready for consumption was collected from the following vegetables: tomato (Lycopersicon esculentum, Mill.), eggplant (Solanum melogena), bell pepper (Capsicum annuum L.), zucchini (Cucurbita pepo $\mathrm{L}$ ) and chard (Beta vulgaris $\mathrm{L}$ ). Collection was performed following a zigzag pattern in the direction of the downslope of each area, collecting 10 fruits per area to make up the sample. The leafy vegetable (chard) was collected applying the same scheme used for fruits, with five whole plants without roots forming one sample. Two collections were carried out (January and November 2011). The samples were washed with distilled water and packed in paper bags, dried in a forced air oven at $65 \stackrel{\circ}{\circ}$ until constant weight and ground in a knife mill.

\section{Water sampling}

The water samples were collected in five reservoirs ( $R-1, R-2$, $R-3, R-4$ and $R-5$ ) used for crop irrigation and one for human consumption (R-6). We collected $200 \mathrm{~mL}$ of water between the $5^{\text {th }}$ and $8^{\text {th }}$ day of every month in 2011, at different points of the reservoir to achieve representative data, avoiding atypically murky points or those with a significant amount of suspended matter. After collection, the samples were immediately acidified in diluted acid, $1 \mathrm{~mL}$ of $\mathrm{HNO}_{3}$ for each $100 \mathrm{~mL}$ of sample, lowering the $\mathrm{pH}$ to 4 . Next, they were stored in a refrigerator (4 $\mathrm{o} C$ ) and subsequently analyzed.

\section{Soil, plant and water sample preparation for chemical analyses}

In order to determine total heavy metal levels, $1 \mathrm{~g}$. of soil and $0.5 \mathrm{~g}$ of plant matter were weighed for each digestion, passed through Teflon tubes and added with $9 \mathrm{~mL}$ of $\mathrm{HNO}_{3}$ and $3 \mathrm{~mL}$ of $\mathrm{HCl}$ (USEPA, 1998). The samples were digested in a microwave (Mars Xpress) and kept in a closed system for $8 \mathrm{~min}$ and $40 \mathrm{sec}$., the time required to reach $175 \stackrel{\circ}{\circ}$, and maintained at this temperature for more than $4 \mathrm{~min}$ and 30 sec. After cooling, the samples were transferred to certified $25 \mathrm{~mL}$ volumetric balloon flasks, topped up with distilled water and the extracts immediately filtered in qualitative filter paper (Macherey Nagel ${ }^{\circledR}$ ).

The digestions and extracts were performed in triplicate, the first two used in determinations and, when the values were different, a third replicate was also determined. The $\mathrm{Cd}, \mathrm{Cu}$, $\mathrm{Mn}, \mathrm{Ni}, \mathrm{Pb}$ and $\mathrm{Zn}$ contents of the extracts, including the water samples, were measured by flame atomic absorption spectrometry (Analyst 800 Perkin Elmer), with the following detection limits: $0.002-0.005-0.05-0.002-0.003$ and $0.002 \mathrm{mg} \mathrm{kg}^{-1}$, for $\mathrm{Cd}, \mathrm{Cu}, \mathrm{Mn}, \mathrm{Ni}, \mathrm{Pb}$ and $\mathrm{Zn}$, respectively. The fraction of available soil heavy metals was obtained by diethylenetriaminepentaacetic acid (DTPA) (Ali et al., 2013). Quality control of the analyses was performed with samples of multi-element reference solutions (spikes), prepared from the $1000 \mathrm{mg} \mathrm{L}^{-1}$ standards (TITRISOL ${ }^{\circledR}$, Merck), with a concentration equal to the central point of the calibration curve of the device, for each chemical element.

In order to identify possible contaminations, the results of heavy metals in soil and water were compared with the parameters established by resolution no. 357 (CONAMA [National Environment Council], 2005; 2009), which contains the guidelines for permissible heavy metal levels in water and soil, respectively. Contents in plants were compared with those recommended by ANVISA (National Health Surveillance Agency) (1965).

\section{Statistical analysis}

The data were submitted to the Student's t-test at $95 \%$ to determine if the values obtained differ from Quality Reference Values (QRVs) recommended and those found in the reference soil of native forest. Pearson's correlation analyses at $5 \%$ and $1 \%$ probability between the total content of heavy metals and the chemical and physical properties of soil were also conducted.

\section{Conclusion}

The results showed that soil with intensive agricultural inputs enhanced total $\mathrm{Mn}, \mathrm{Cu}$ and $\mathrm{Zn}$ levels. High levels of $\mathrm{Ni}$ were found in agricultural and forest soils, indicating that this may be associated with its presence in the original soil material. $\mathrm{Pb}$ and $\mathrm{Ni}$ levels exceeded the maximum values allowed by ANVISA (Brazilian Health Surveillance Agency) for all plant samples examined. Bell pepper and chard showed the highest levels of $\mathrm{Pb}$ and $\mathrm{Ni}$, suggesting that these species accumulate more of these metals than the other species studied. $\mathrm{Cd}, \mathrm{Ni}$ and $\mathrm{Pb}$ levels surpassed the values established by CONAMA (National Environment Council) for 
human consumption and irrigation water. These levels varied seasonally as a function of rainfall. Preventive monitoring and planning of fertilizer applications, avoiding fertilizing the soil near the rainy season, are alternatives to establish normal heavy metal levels in water for irrigation and domestic use. Moreover, bell pepper and chard crops should be avoided in $\mathrm{Pb}$ and Ni contaminated soils.

\section{Acknowledgments}

The authors express their gratitude to UFRPE (Rural Federal University of Pernambuco) and to CNPq (National Council for Scientific and Technological Development) for the scholarship granted to the first author.

\section{References}

Ali H, Khan E, Sajad MA (2013) Phytoremediation of heavy metals - Concepts and applications. Chemosphere. 91:869-881.

Anvisa - Agência Nacional de Vigilância Sanitária (1965) Decreto no 55.871, 26/03/1965. Available online at: http://www.anvisa.gov.br/legis/decretos/55871_65.htm (Accessed 28 November 2016).

Araújo WS, Amaral Sobrinho NMB, Mazur N, Gomes PC (2002) Relação entre adsorção de metais pesados e atributos químicos e físicos de classes de solos do Brasil. $R$ Bras Ci Solo. 26:17-27.

Atafar Z, Mesdaghinia A, Nouri J, Homaee M, Yunesian M, Ahmadimoghaddam M, Mahvi AH (2010) Effect of fertilizer application on soil heavy metal concentration. Environ Monit Assess. 160:83-89.

Biondi CM, Nascimento CWA, Fabricio Neta AB, Ribeiro MR (2011) Concentrations of $\mathrm{Fe}, \mathrm{Mn}, \mathrm{Zn}, \mathrm{Cu}, \mathrm{Ni}$ and $\mathrm{Co}$ in benchmark soils of Pernambuco, Brazil. R Bras Ci Solo. 35:1057-1066.

Brasil - Ministério da Agricultura e Reforma Agrária (1973) Levantamento exploratório: reconhecimento de solos do Estado de Pernambuco. Rio de Janeiro, DNPEA.

Casali CA, Moterle DF, Rheinheimer DS, Brunetto G, Corcini ALM, Kaminski J, Melo GWB (2008) Formas e dessorção de cobre em solos cultivados com videira na Serra Gaúcha do Rio Grande do Sul. R Bras Ci Solo. 32:1479-1487.

Conama - Conselho Nacional do Meio Ambiente (2005) Lei no 357, 17/03/2005. Available online at: http://www.mma.gov.br/port/conama/res/res05/res3570 5.pdf (Accessed 07 March 2016).

Conama - Conselho Nacional do Meio Ambiente (2009) Resolução no 420, 28/12/2009. Available online at: http://www.mma.gov.br/port/conama/res/res09/res42 009.pdf (Accessed 07 March 2016).

Embrapa - Empresa Brasileira de Pesquisa Agropecuária (2013) Sistema brasileiro de classificação de solos (2nd ed.) Embrapa, Rio de Janeiro.

Fernandes RBA, Luz WV, Fontes MPF, Fontes LEF (2007) Avaliação da concentração de metais pesados em áreas olerícolas no Estado de Minas Gerais. Rev Bras Eng Agríc Ambient. 11:81-93.

Gupta DK, Chatterjee S, Datta S, Veer V, Walther C (2014) Role of phosphate fertilizers in heavy metal uptake and detoxification of toxic metals. Chemosphere. 108:134-144. luss Working Group WRB - World reference base for soil resources (2015) International soil classification system for naming soils and creating legends for soil maps. World Soil Resources, Rome (Report FAO, 106).

Jones JB, Lacy GH, Bouzar H, Stall RE, Schaad NW (2004) Reclassification of the Xanthomonads associated with bacterial spot disease of tomato pepper. Syst Appl Microbiol. 27:755-762.

Khan F, Sarfaraz N, Shaheen S, Saeed A, Sial ZK, Khan SJ, Shafiq M (2012) Comparative evaluation of copper, cobalt, cadmium and iron scavenging efficiency by in-vivo and invitro grown Momordica charantia using atomic absorption spectroscopy. J Med Plants Res. 6:3301-3305.

Lair GJ, Gerzabek MH, Haberhauer G, Jakusch M, Kirchmann $\mathrm{H}$ (2006) Response of the sorption behavior of $\mathrm{Cu}, \mathrm{Cd}$, and $\mathrm{Zn}$ to different soil management. J Plant Nutr Soil Sci. 169:1-9.

Mahmood A, Malik RN (2014) Human health risk assessment of heavy metals via consumption of contaminated vegetables collected from different irrigation sources in Lahore. Arab J Chem. 7:91-99.

McLaughlin MJ, Smolders E, Degryse F, Rietra R (2011) Uptake of metals from soil into vegetables. In: Swartjes FA (ed) Dealing with contaminated sites: from theory towards practical application. Springer, Heidelberg.

Melo EDC, Nascimento CWA, Santos ACQ, Silva AS (2008) Disponibilidade e fracionamento de $\mathrm{Cd}, \mathrm{Pb}, \mathrm{Cu}$ e $\mathrm{Zn}$ em função do $\mathrm{pH}$ e tempo de incubação com o solo. Ciênc Agrotec. 32:776-784.

Nziguheba G, Smolders E (2008) Inputs of trace elements in agricultural soils via phosphate fertilizers in European countries. Sci Total Environ. 390:53-57.

Pingali PL (2012) Green revolution: impacts, limits and the path ahead Proc Natl Acad Sci. 109:12302-12308.

Preston W, Silva YJAB, Nascimento CWA, Cunha KPV, Silva DJ, Ferreira HA (2016) Soil contamination by heavy metals in vineyard of a semiarid region: An approach using multivariate analysis. Geoderma Regional. 7:357-365.

Raij B, Cantarella H, Quaggio JA, Furlani AMC (1997) Recomendações de adubação e calagem para o estado de São Paulo. 2nd ed. Instituto Agronômico, Campinas.

Ramalho JFGP, Amaral Sobrinho NMB, Velloso AX (2000) Contaminação da microbacia de Caetés com metais pesados pelo uso de agroquímicos. Pesq Agropec Bras. 35:1289-1303.

Silva LS, Galindo ICL, Nascimento CWA, Gomes RP, Campos MCC, Freitas L, Oliveira IA (2016) Heavy metal contents in Latosols cultivated with vegetable crops. Pesqui Agropecu Trop. 46:391-400.

Silva MLS, Vitti GC (2008) Fracionamento de metais pesados em solo contaminado antes e após cultivo de arroz. Quim Nova. 31:1385-1391.

Singh R, Singh DP, Kumar N, Bhargava SK, Barman SC (2010) Accumulation and translocation of heavy metals in soil and plants from fly ash contaminated area. J Environ Biol. 31:421-430.

Usepa - United States Environmental Protection Agency (1998) Method 3051A: microwave assisted acid digestion of sediments. US Government Printing Office, Washington. Weingerl V, Kerin D (2000) Distribution of zinc in vineyard areas treated with zinc containing phytopharmaceuticals. Acta Chim Slov. 47:453-467. 